Prepared in cooperation with the Bureau of Reclamation

\title{
Modeling a 2- and 4-Foot Drawdown in the Link River to Keno Dam Reach of the Upper Klamath River, South-Central Oregon
}

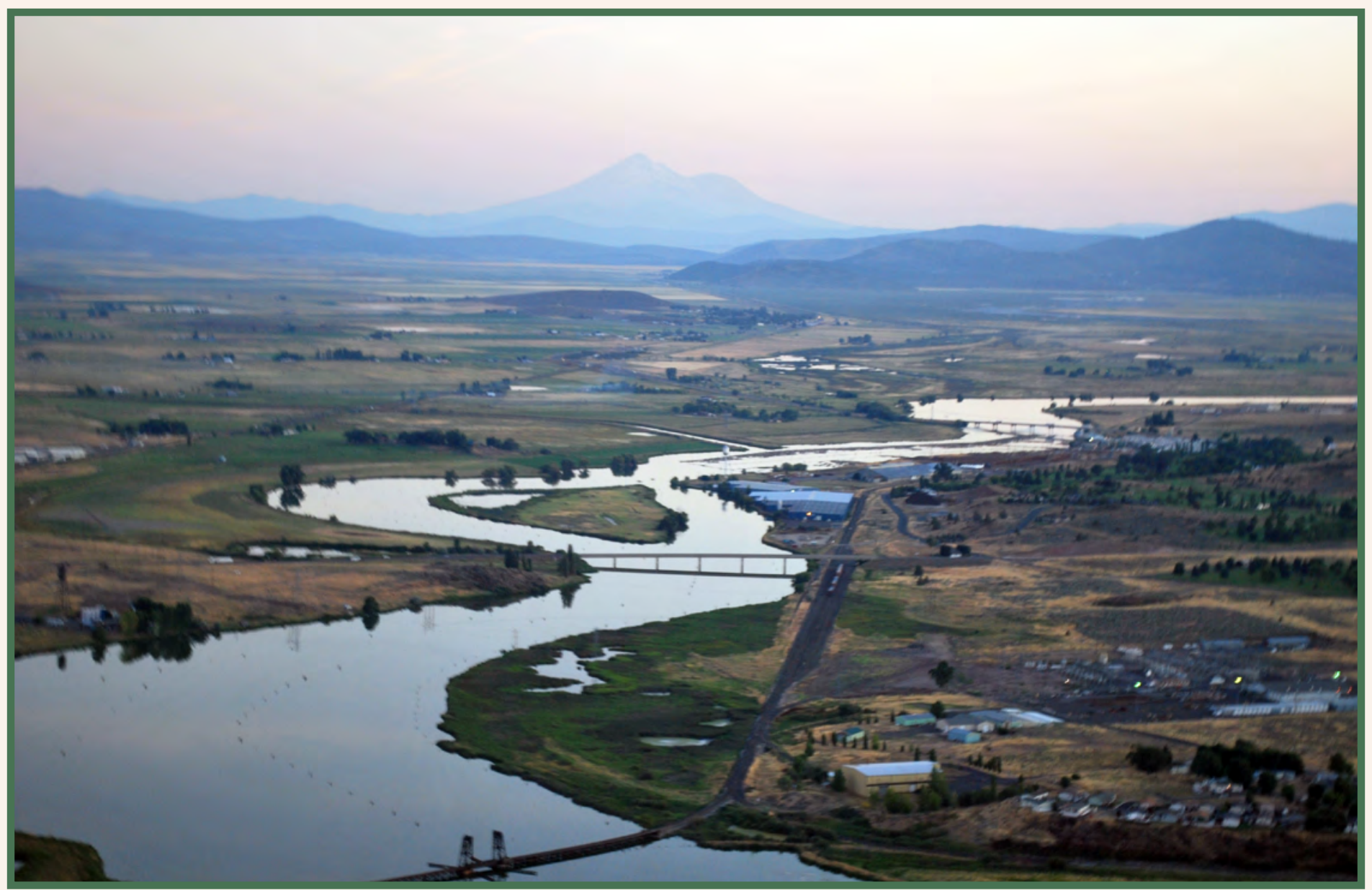

Scientific Investigations Report 2020-5001 
Cover: View looking south along the Link River to Keno Dam reach of the upper Klamath River, south-Central Oregon, with Mount Shasta, northern California, in the background. Photograph by Chauncey Anderson, U.S. Geological Survey, August 2009. 


\section{Modeling a 2- and 4-Foot Drawdown in the Link River to Keno Dam Reach of the Upper Klamath River, South-Central Oregon}

By Annett B. Sullivan and Stewart A. Rounds

Prepared in cooperation with the Bureau of Reclamation

Scientific Investigations Report 2020-5001 


\title{
U.S. Department of the Interior \\ DAVID BERNHARDT, Secretary
}

\author{
U.S. Geological Survey \\ James F. Reilly II, Director
}

U.S. Geological Survey, Reston, Virginia: 2020

For more information on the USGS - the Federal source for science about the Earth, its natural and living resources, natural hazards, and the environment—visit https://www.usgs.gov or call 1-888-ASK-USGS.

For an overview of USGS information products, including maps, imagery, and publications, visit https://store.usgs.gov/.

Any use of trade, firm, or product names is for descriptive purposes only and does not imply endorsement by the U.S. Government.

Although this information product, for the most part, is in the public domain, it also may contain copyrighted materials as noted in the text. Permission to reproduce copyrighted items must be secured from the copyright owner.

Suggested citation:

Sullivan, A.B., and Rounds, S.A., 2020, Modeling a 2- and 4-foot drawdown in the Link River to Keno Dam reach of the upper Klamath River, south-central Oregon: U.S. Geological Survey Scientific Investigations Report 2020-5001, 18 p., https://doi.org/10.3133/sir20205001.

ISSN 2328-0328 (online) 


\section{Contents}

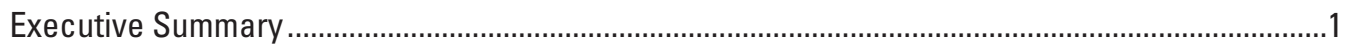

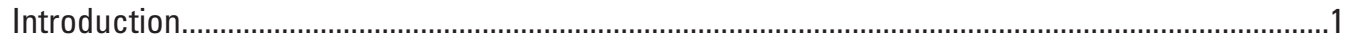

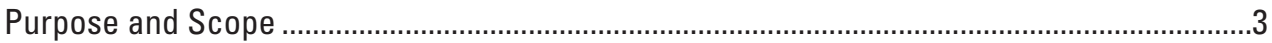

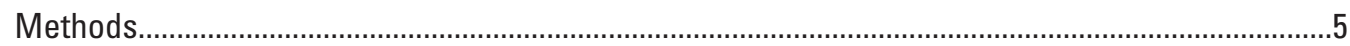

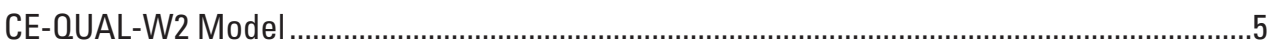

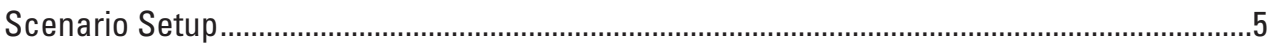

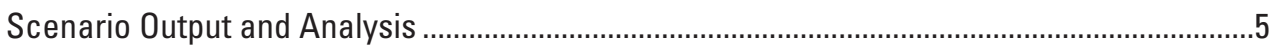

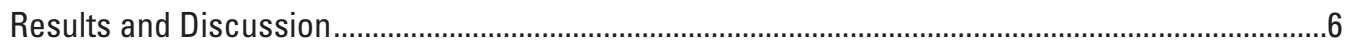

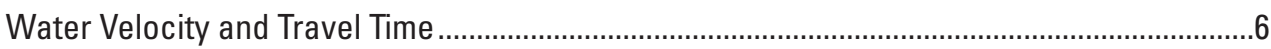

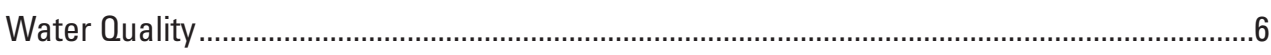

Model Scenarios Without Macrophytes ........................................................................

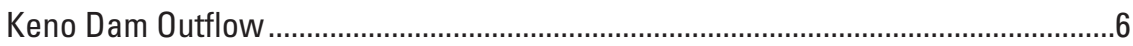

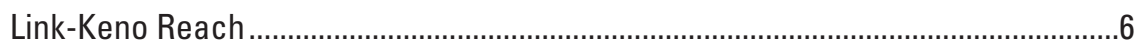

Algae and Settled Organic Matter ...............................................................6

Dissolved Oxygen ..............................................................................................

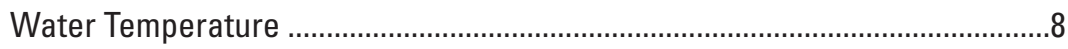

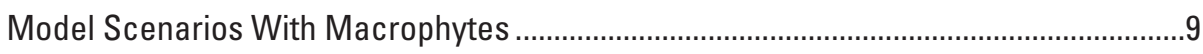

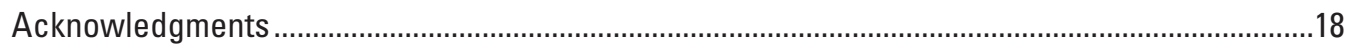

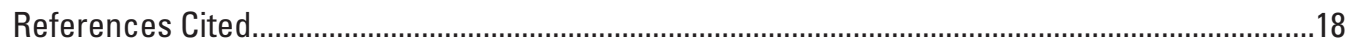

\section{Figures}

1. Map showing Link River to Keno Dam reach of the Klamath River, south-central Oregon

2. Graph showing measured water-surface elevation at three locations in Klamath River from Link River mouth to Keno Dam (Link-Keno reach), south-central Oregon, 1907-08, and modeled water-surface elevation in the 2007 base case and the 2- and 4-foot drawdown scenarios.

3. Side view of the two-dimensional hydrodynamic and water quality model (CE-OUAL-W2) grid showing the model segments and the model layers, from Link River to Keno Dam, south-central Oregon

4. Graphs showing modeled water velocity in the year 2007 base case, and modeled velocity difference between the 4-foot drawdown scenario and the base-case model, in the Link River to Keno Dam reach of the Klamath River, south-central Oregon.

5. Graphs showing model tracer results from addition of a hypothetical tracer at the mouth of Link River and downstream tracer concentrations at the Keno Dam outflow indicating the time required for the tracer peak to reach Keno Dam, south-central Oregon, during 2007

6. Graphs showing modeled flow, temperature, and water-quality constituents in the outflow of Keno Dam for the base case, and the 2- and 4-foot drawdown scenarios, in the Link River to Keno Dam reach of the Klamath River, south-central Oregon, during 2007 
7. Graphs showing modeled chlorophyll a concentration for the year 2007 base case and the 4-foot drawdown scenario, in the Link River to Keno Dam reach of the Klamath River, south-central Oregon

8. Graph showing modeled difference in segment-averaged chlorophyll a concentration between the 4-foot drawdown and the base-case scenarios, and depth profiles showing chlorophyll $a$ at model segment 38 near Miller Island for the base case and 4-foot drawdown scenario, in the Link River to Keno Dam reach of the Klamath River, south-central Oregon, during 2007

9. Graphs showing modeled settled organic matter in the first-order sediment compartment for the year 2007 base case, and the difference in modeled settled organic matter mass between the 4-foot drawdown scenario and the base case, in the Link River to Keno Dam reach of the Klamath River, south-central Oregon

10. Graph showing modeled difference between dissolved oxygen concentration in the 4-foot drawdown scenario and the year 2007 base case, in the Link River to Keno Dam reach of the Klamath River, south-central Oregon

11. Dissolved-oxygen profiles showing changes in dissolved oxygen concentrations at segments 38 (Miller Island) and 95 (Keno Bridge), with depth, during 2007, in the Link River to Keno Dam reach of the Klamath River, south-central Oregon

12. Graph showing modeled difference between water temperature in the 4-foot drawdown scenario and the year 2007 base case, in the Link River to Keno Dam reach of the Klamath River, south-central Oregon

13. Water-temperature profiles showing changes in water temperature at segment 38 (Miller Island), with depth, during 2007, in the Link River to Keno Dam reach of the Klamath River, south-central Oregon

14. Graphs showing modeled flow, temperature, and water-quality constituents in the outflow of Keno Dam for the base case and 4-foot drawdown scenarios, Klamath River, south-central Oregon

15. Graphs showing dissolved-oxygen production and respiration fluxes, as modeled with the presence of macrophytes, for macrophytes and algae for the entire Link-Keno reach, Klamath River, south-central Oregon

16. Dissolved oxygen profiles showing changes in dissolved oxygen concentrations at segments 38 (Miller Island) and 95 (Keno Bridge), with depth, during 2007 


\section{Conversion Factors}

U.S. customary units to International System of Units

\begin{tabular}{lcl}
\hline \multicolumn{1}{c}{ Multiply } & By & \multicolumn{1}{c}{ To obtain } \\
\hline foot $(\mathrm{ft})$ & Length & \\
mile $(\mathrm{mi})$ & 0.3048 & meter $(\mathrm{m})$ \\
\hline & 1.609 & kilometer $(\mathrm{km})$ \\
\hline foot per second $(\mathrm{ft} / \mathrm{s})$ & Flow rate & \\
cubic foot per second $(\mathrm{ft} 3 / \mathrm{s})$ & 0.3048 & meter per second $(\mathrm{m} / \mathrm{s})$ \\
\hline
\end{tabular}

International System of Units to U.S. customary units

\begin{tabular}{|c|c|c|}
\hline Multiply & By & To obtain \\
\hline \multicolumn{3}{|c|}{ Length } \\
\hline meter $(\mathrm{m})$ & 3.281 & foot $(\mathrm{ft})$ \\
\hline kilometer $(\mathrm{km})$ & 0.6214 & mile (mi) \\
\hline \multicolumn{3}{|c|}{ Area } \\
\hline square meter $\left(\mathrm{m}^{2}\right)$ & 0.0002471 & acre \\
\hline square meter $\left(\mathrm{m}^{2}\right)$ & 10.76 & square foot $\left(\mathrm{ft}^{2}\right)$ \\
\hline \multicolumn{3}{|c|}{ Volume } \\
\hline liter $(\mathrm{L})$ & 0.2642 & gallon (gal) \\
\hline \multicolumn{3}{|c|}{ Flow rate } \\
\hline meter per second $(\mathrm{m} / \mathrm{s})$ & 3.281 & foot per second $(\mathrm{ft} / \mathrm{s})$ \\
\hline cubic meter per second $\left(\mathrm{m}^{3} / \mathrm{s}\right)$ & 35.31 & cubic foot per second $\left(\mathrm{ft}^{3} / \mathrm{s}\right)$ \\
\hline \multicolumn{3}{|c|}{ Mass } \\
\hline microgram $(\mu \mathrm{g})$ & 0.00000003527 & ounce, avoirdupois (oz) \\
\hline milligram (mg) & 0.00003527 & ounce, avoirdupois (oz) \\
\hline $\operatorname{gram}(\mathrm{g})$ & 0.03527 & ounce, avoirdupois (oz) \\
\hline kilogram (kg) & 2.205 & pound avoirdupois (lb) \\
\hline metric ton $(\mathrm{t})$ & 1.102 & ton, short $[2,000 \mathrm{lb}]$ \\
\hline
\end{tabular}

Temperature in degrees Celsius $\left({ }^{\circ} \mathrm{C}\right)$ may be converted to degrees Fahrenheit $\left({ }^{\circ} \mathrm{F}\right)$ as follows:

${ }^{\circ} \mathrm{F}=\left(1.8 \times{ }^{\circ} \mathrm{C}\right)+32$. 


\section{Datums}

Horizontal coordinate information is referenced to the North American Datum of 1983 (NAD 83).

A local vertical datum (Upper Klamath Lake Vertical Datum [UKLVD]) is used, established by the Bureau of Reclamation. For the purpose of this report, the conversion is UKLVD -1.78 feet $=$ National Geodetic Vertical Datum of 1929 (NGVD 29).

Elevation, as used in this report, refers to distance above the vertical datum.

\section{Supplemental Information}

Concentrations of chemical constituents in water are given in either milligrams per liter (mg/L) or micrograms per liter $(\mu \mathrm{g} / \mathrm{L})$.

\section{Abbreviations}

CE-QUAL-W2 Two-dimensional hydrodynamic and water-quality model

Link-Keno Klamath River from Link River mouth to Keno Dam

Reclamation Bureau of Reclamation

USGS United States Geological Survey 


\title{
Modeling a 2- and 4-Foot Drawdown in the Link River to Keno Dam Reach of the Upper Klamath River, South-Central Oregon
}

\author{
By Annett B. Sullivan and Stewart A. Rounds
}

\section{Executive Summary}

The most upstream, pooled reach of the Klamath River in south-central Oregon, from Link River mouth to Keno Dam (Link-Keno), has a water-surface elevation that remains relatively constant throughout the year. Two model scenarios, using an existing two-dimensional hydrodynamic and water-quality model (CE-QUAL-W2), were constructed to examine the effects of lowering the water-surface elevation by 2 and 4 feet (ft) ( 0.61 and 1.2 meters) throughout an entire calendar year to mimic some of the potential effects of removal or modification of Keno Dam. Model results for these drawdown scenarios were analyzed for changes in velocity, travel time, water temperature, total dissolved solids, inorganic suspended sediment, nutrients, organic matter, chlorophyll $a$, and dissolved oxygen, compared to the base-case model. The model used in this study had been previously calibrated with the presence of aquatic plants (macrophytes). However, most model analyses were completed for model runs where macrophytes were "turned off" because the species, abundance, and distribution of macrophytes in a lowered-water scenario were all highly uncertain. For comparison, a few model scenario runs were completed with macrophytes enabled within the model. Findings from this study include the following:

- Modeled water velocity increased and travel time decreased substantially throughout the reach with the 2- and 4-ft drawdown scenarios, with travel time roughly halved in the 4-ft scenario under unchanged flow conditions.

- For many water-quality constituents in the drawdown scenarios, the model showed little to no change in outflow concentrations at Keno Dam compared to the base case, which represents conditions based on year 2007 water-level elevations. However, chlorophyll $a$ and particulate organic carbon concentrations increased in the Keno Dam outflow in summer with the drawdowns. This seemed to be related to the increased water velocity. As suspended algae and other particulate organic matter such as dead algal cells and detritus moved farther downstream with the faster velocity, there was relatively less deposition of that material in the most upstream model segments and relatively more deposition in downstream segments of the Link-Keno reach, especially in summer and autumn, the period with the largest algae bloom.

- Despite minor differences in the Keno Dam outflow, modeled dissolved oxygen concentration and water temperature showed some changes in the Link-Keno reach compared to the base case, with differences as large as 2 milligrams per liter and 2 degrees Celsius, respectively, computed as segment averages and daily averages.

- With macrophytes enabled, the model outflow in the drawdown scenarios showed a decrease in dissolved oxygen concentration in mid-summer that seemed to be related to decreased macrophyte abundance and primary production in those scenarios. The withmacrophyte model results have greater uncertainty, but the results indicated that macrophytes are likely to be an important factor in the dissolved oxygen budget under reduced water-surface elevations.

\section{Introduction}

The Klamath River flows approximately $255 \mathrm{mi}$ (410 $\mathrm{km}$ ) from the mouth of Link River near Upper Klamath Lake to the Pacific Ocean. The first $20 \mathrm{mi}(32 \mathrm{~km})$ of the Klamath River are bounded by the mouth of Link River at the upstream end and Keno Dam at the downstream end (Link-Keno) (fig. 1). This reach was designated as "water-quality limited" for exceeding ammonia toxicity and not attaining minimum dissolved oxygen criteria year-round, and failing to meet $\mathrm{pH}$ and chlorophyll $a$ criteria in summer. This river reach receives large algal and nutrient loads in summer from Upper Klamath Lake, which is just upstream of Link River, with additional inputs from nonpoint and point sources in the Link-Keno reach. A Total Maximum Daily Load has been issued for the upper Klamath River including this reach (Oregon Department of Environmental Quality, 2018). 


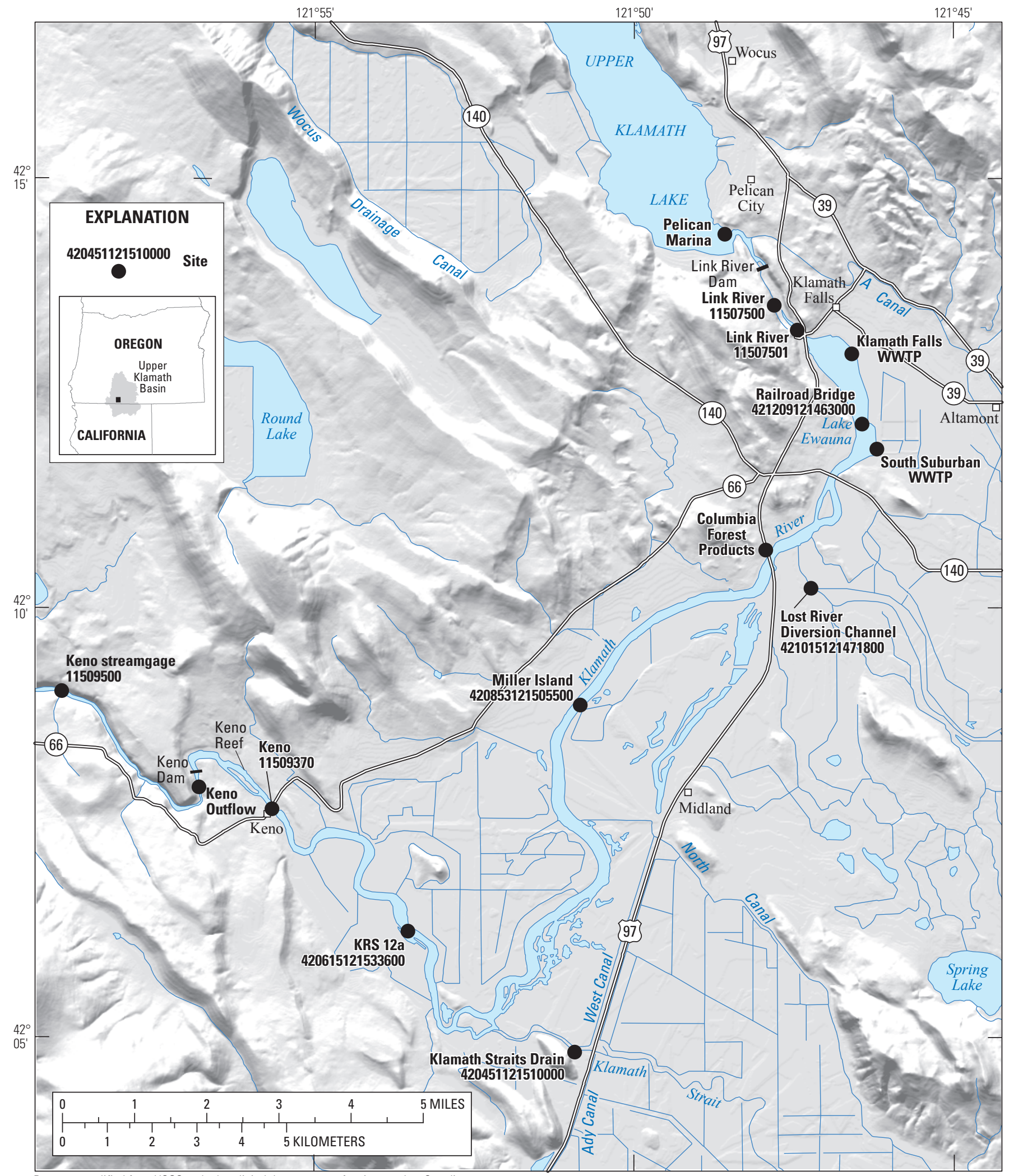

Basemap modified from USGS and other digital data sources of various scales. Coordinate reference system is UTM, Zone 10N; datum is North American Datum of 1983.

Figure 1. Link River to Keno Dam reach of the Klamath River, south-central Oregon. WWTP, wastewater treatment plant. 
A geologic feature made of basalt rock known as the Keno reef, located between Keno Dam and the town of Keno (fig. 1), served as a historical water-level control in this reach. U.S. Geological Survey (USGS) measurements of water-surface elevation at three locations in the Link-Keno reach in 1907 were similar and all three varied seasonally by about $2 \mathrm{ft}$ (0.61 m; fig. 2; Hoyt and others, 1913). Those reported measurements did not document the datum used by those three streamgages but the datum was assumed to be equal to the Reclamation datum that was used for the model and for other nearby streamgages in the early 1900s. These historical elevations were within $2.5 \mathrm{ft}(0.76 \mathrm{~m})$ of the water-surface elevation of Link-Keno in recent years (fig. 2).

Keno reef was notched and excavated twice to increase flow through this part of the Klamath River and to allow the drainage of upstream lands. The first notching occurred in 1908 (Dicken and Dicken, 1985). The second notching of Keno reef occurred in the mid-1960s around the time that Keno Dam was constructed.

Keno Dam was built in 1966 and serves as the present-day control for the water-surface elevation in the Link-Keno reach. In most years, water-surface elevation is maintained near 4,085.5 ft $(1,245.3 \mathrm{~m})$. In this modeling study, the water-surface elevation was simulated with measured conditions from 2007, called the base case, and with drawdown scenarios that lowered the water surface by 2 and $4 \mathrm{ft}$ (0.61 and $1.2 \mathrm{~m}$; figs. 2, 3). Year 2007 was selected because it had annual average and annual mean flows that were moderate for the years modeled and the water-quality calibration was based on a rich dataset.

The U.S. Geological Survey (USGS), Bureau of Reclamation (Reclamation), and Watercourse Engineering, Inc., are collaborating to better understand water quality in the Link-Keno reach of the Klamath River. One outcome of this collaboration was a calibrated water-quality model (Sullivan and others, 2011; Sullivan, Rounds, and others, 2013). The model has already been used to provide insights into the potential effects of management strategies on water quality (Sullivan, Sogutlugil, and others, 2013; Sullivan and others, 2014).

\section{Purpose and Scope}

The purpose of this study was to use an existing calibrated two-dimensional hydrodynamic and water-quality model (CE-QUAL-W2) of the Link-Keno reach of the Klamath River to simulate the flow, velocity, water temperature, and water-quality effects of a 2- and 4-ft drawdown of the water-surface elevation for the period of a calendar year.

The calibrated model (calendar year 2007) was used in this study as the base case, in which water quality in the Link-Keno reach and the outflow from Keno Dam were simulated. Changes in the water level were superimposed on top of those base-case conditions for the drawdown scenarios. Model results were output at an hourly time step for all model layers for each model segment as well as Keno Dam outflow. Model output included water-surface elevation, flow, velocity, travel time, water temperature, total dissolved solids, inorganic suspended sediment, nutrients, organic matter, chlorophyll $a$, and dissolved oxygen. This report documents the results of this study, and compares and discusses the simulated differences in model results between the drawdown scenarios and the base case. 


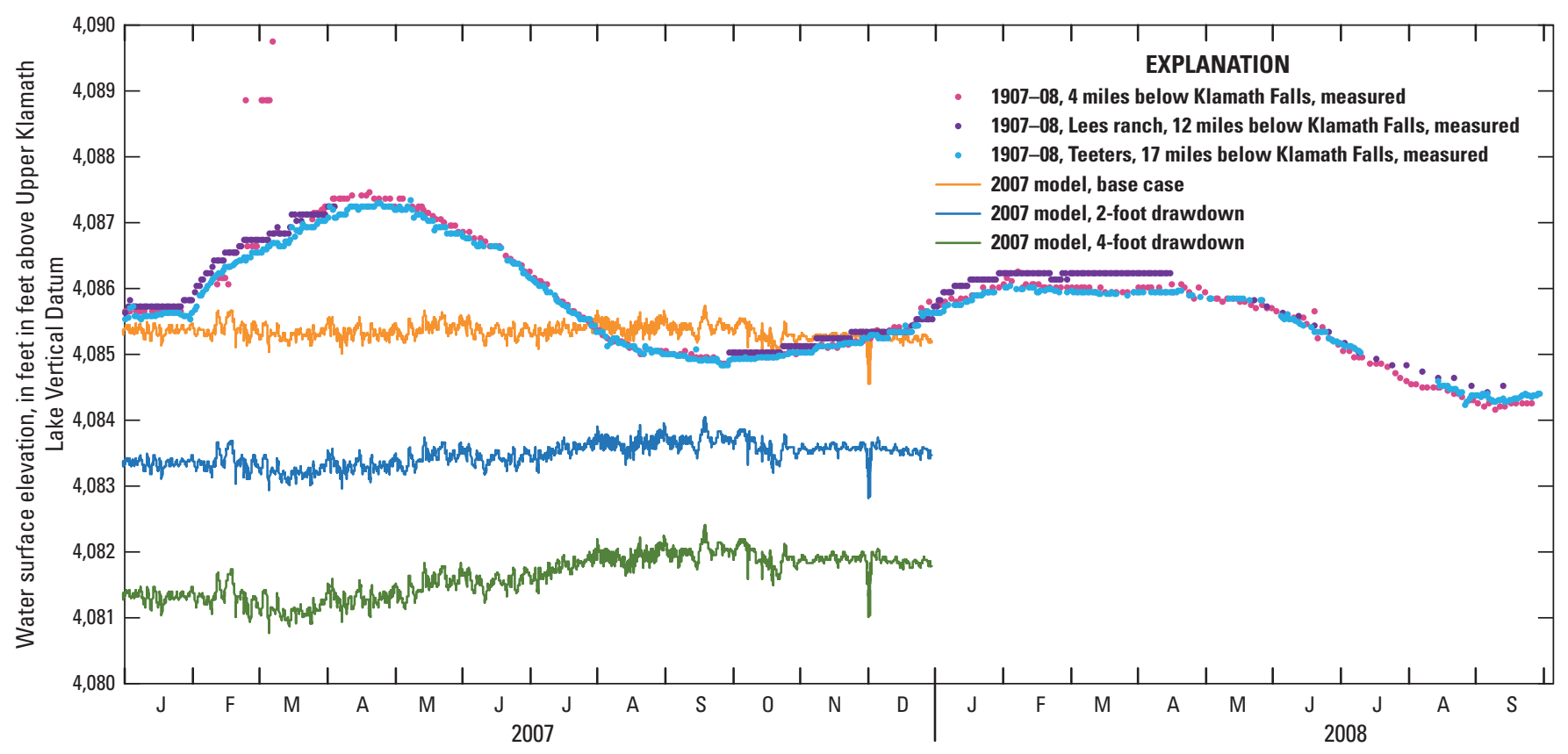

Figure 2. Measured water-surface elevation at three locations in Klamath River from Link River mouth to Keno Dam (Link-Keno reach), south-central Oregon, 1907-08, and modeled water-surface elevation in the 2007 base case and the 2- and 4-foot drawdown scenarios.

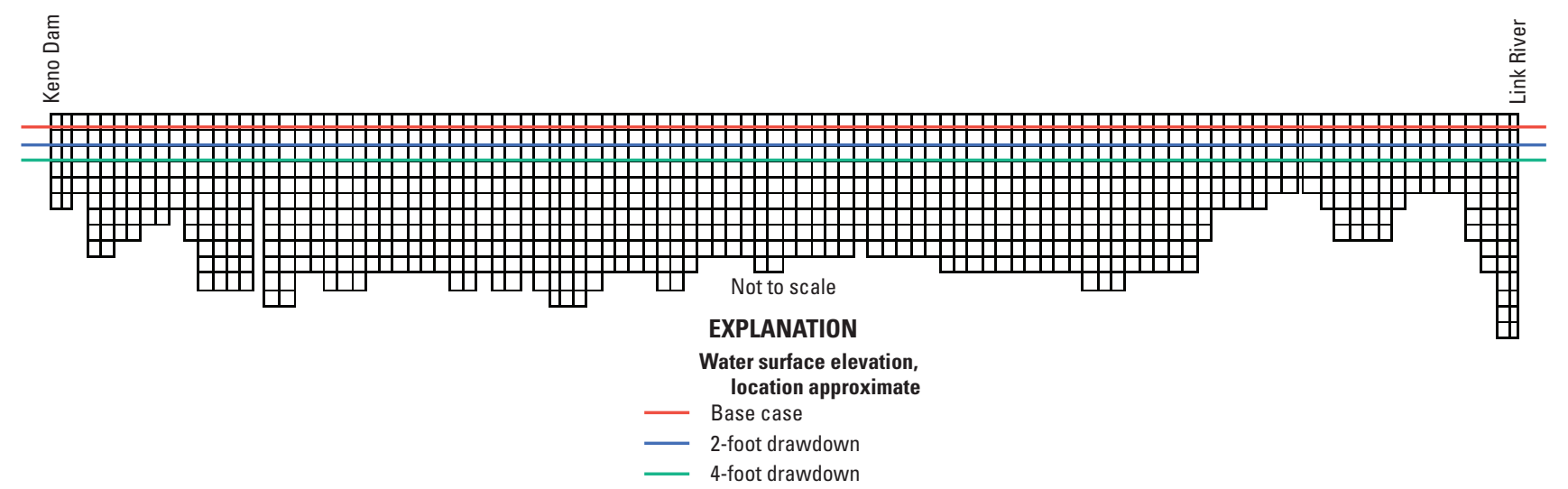

Figure 3. Two-dimensional hydrodynamic and water quality model (CE-QUAL-W2) grid showing the model segments (columns of cells, right to left) and the model layers (rows, top to bottom), from Link River (right) to Keno Dam (left), south-central Oregon. Approximate locations of the water-surface elevation for the base case, 2-foot drawdown, and 4-foot drawdown are shown. 


\section{Methods}

This study used a previously calibrated CE-QUAL-W2 model for calendar year 2007 (Sullivan and others, 2011). Two scenarios were constructed with the water-surface elevation lowered by 2 and $4 \mathrm{ft}$, and the model output was analyzed for changes in flow, water temperature, and water quality, compared to the base-case model conditions with no changes.

\section{CE-QUAL-W2 Model}

CE-QUAL-W2 is a two-dimensional mechanistic flow, temperature, and water-quality model used to simulate variability both longitudinally (from upstream to downstream) and vertically. The third dimension, from bank to bank, is considered to be well mixed, which is a good approximation for many long and narrow waterbodies such as the upper Klamath River that tend to thermally stratify. This is because variations in the vertical dimension in these waterbodies typically are often far greater than those in the lateral dimension. The CE-QUAL-W2 model is capable of simulating velocity, flow, temperature, and water quality in lakes, reservoirs, rivers, and estuarine systems. The CE-QUAL-W2 model has been applied successfully to hundreds of river and reservoir systems around the world and is under active and ongoing development and enhancement (Cole and Wells, 2008). It has proved to be a useful model for planning and management, and for enhancing our understanding of water-quality status and processes in river and reservoir systems.

The USGS upper Klamath River model CE-QUAL-W2 grid consists of 102 segments in the main model branch that connect in the direction of flow; segments average $1,009 \mathrm{ft}$ (308 m) in length. Each segment represents a cross-sectional shape of the river channel, with stacked layers of varying width from the river surface to the channel bottom. Vertical layers in the grid are $2 \mathrm{ft}(0.61 \mathrm{~m})$ in height. The original model grid was developed to provide averaged bathymetric information for each segment. For this scenario, with the decreased water levels, the maximum elevation of basaltic features on the river bottom could become more important. Thus, some minor modifications were made to the segment lengths and layer widths for segments 16, 17, 18, 90, 91, 92, 97 and 98 for the scenarios described in this report. The grid volume was unchanged. Base-case model runs with the original and modified grid indicated no substantial change in model results. A side-view of the model grid from the mouth of Link River to Keno Dam depicting the model segments and layers is shown in figure 3.

The model uses a variable time step that can be as short as 1 second, but can produce output for all constituents in all layers and segments at a user-selected time interval. The model was constructed and calibrated for calendar years
2006-09 and 2011 (Sullivan and others, 2011; Sullivan, Rounds, and others, 2013); year 2007 was selected for this study as a representative year.

\section{Scenario Setup}

Water-surface elevations for the drawdown scenarios were adjusted by lowering the initial water-surface elevations on January 1 in the representative year by exactly 2 or $4 \mathrm{ft}$. The model uses flow boundary conditions at the upstream (Link River) and downstream (Keno Dam) ends of the reach; therefore, the change in the initial water-surface elevation was sufficient to maintain the drawdown through the rest of the year, with some differences due to varying levels of evaporation over the altered surface widths. The actual elevation difference relative to the base case during the year varied from 1.6 to $2.2 \mathrm{ft}$, with an average difference of $1.9 \mathrm{ft}$, for the " 2 -ft" scenario, and from 3.3 to $4.3 \mathrm{ft}$, with an average difference of $3.8 \mathrm{ft}$, for the " $4-\mathrm{ft}$ " scenario. The average river width was about $750 \mathrm{ft}(229 \mathrm{~m})$ in the base case, about $690 \mathrm{ft}$ $(210 \mathrm{~m})$ in the 2 -ft drawdown scenario, and about $600 \mathrm{ft}$ (183 $\mathrm{m})$ in the 4-ft drawdown scenario.

A hypothetical tracer test was run with the model using the "generic" water-quality constituent capability of the CE-QUAL-W2 model. This type of tracer test can be used to analyze travel time differences between the regular and altered scenarios. The numerical tracer was added at the model upstream boundary at the mouth of Link River, and the model results for the outflow at Keno Dam were analyzed to determine when the tracer peak arrived.

The original calibrated model had been constructed and calibrated with macrophytes (aquatic plants) active through the model reach, based on data from a field survey (Sullivan, Rounds, and others, 2013). Because macrophyte species, abundance, and distribution have greater uncertainty in a lowered water-surface elevation scenario, they were "turned off" in the first set of model scenarios. A second set of model runs included macrophytes as part of a sensitivity analysis.

\section{Scenario Output and Analysis}

The model provided hourly results for all cells in the model grid, and at Keno Dam. Three separate outflows at Keno Dam are specified in the model: the spill gates, a sluice conduit, and a fish ladder. The model provided results for these outlets separately and as a whole; the latter total outflow was used in this study. Postprocessing of model output included the calculation of segment-average results, combining results from all layers weighted by cell volume. Color index maps over space and time were produced to visualize model results over the entire year and for every model segment. These plots included depth-averaged concentration and daily average concentration results. 


\section{Results and Discussion}

Results for the model scenarios are presented in this section, starting with water velocity and travel time, and followed by various water-quality constituents. Because the 4-ft drawdown was the larger departure from the base-case scenario, those results were included in this report more often than results from the $2-\mathrm{ft}$ drawdown.

\section{Water Velocity and Travel Time}

Modeled segment-average velocities ranged from about 0 to $1.0 \mathrm{ft} / \mathrm{s}(0$ to $0.3 \mathrm{~m} / \mathrm{s})$ in 2007 (fig. $4 A$ ). August and September velocities were lowest overall, which was expected because streamflow in this reach tends to be lowest at that time of year, due to the dry summer climate and increased diversions for agriculture and other uses. With a modeled 4- $\mathrm{ft}$ decrease in water-surface elevation, segment-average velocity increased by as much as double in all segments on almost all dates throughout the year (fig. 4B). The largest velocity increase was at the shallower segments just upstream of Keno Dam and near the inflow of the Lost River Diversion Channel. Velocities also increased during high-flow periods; flows in March 2007 were as high as 2,800 ft3/s (79.3 m³/s).

Model tracer test results showed that a lowered water-surface elevation resulted in faster travel times and higher velocities through the Link-Keno reach for the same flow conditions (fig. 5). For a tracer test starting on April 1, 2007 with flow at $2,154 \mathrm{ft} 3 / \mathrm{s}(61.0 \mathrm{~m} 3 / \mathrm{s})$, a hypothetical model tracer added at the mouth of Link River took 5.2 days (peak concentration) to traverse the reach and exit at Keno Dam under base-case conditions. With the water surface lowered by $4 \mathrm{ft}$, the tracer took only 2.7 days ( 52 percent of the base case) to travel the same distance. For a tracer test starting on September 7, 2007 under a lower flow of $565 \mathrm{ft} 3 / \mathrm{s}(16.0$ $\mathrm{m}^{3} / \mathrm{s}$ ), the peak tracer concentration took 11.1 days to traverse the Link-Keno reach for the base case. In the 4-ft drawdown scenario, the tracer required only 6.7 days ( 60 percent of the base case) to traverse the same distance. The decreased travel time could affect processes such as water-quality reactions that take place over time and also the settling of particulate organic matter, sediment, or algae.

\section{Water Quality}

Results of the base-case and drawdown scenarios were compared at the Keno Dam outflow and throughout the Link-Keno reach. The comparison at Keno Dam provides a cumulative overview of modeled water-quality changes throughout the reach. Simulations were first run without the presence of macrophytes (aquatic plants) because a substantial decrease in water level could have a large effect on the presence and amount of macrophytes, and few data exist to determine how the macrophytes might change in such a scenario. A second set of scenarios were run with macrophytes as a sensitivity test to determine their potential effect on river water quality.

\section{Model Scenarios Without Macrophytes}

\section{Keno Dam Outflow}

With macrophytes "turned off," simulated changes in water quality at Keno Dam seemed to be relatively minor between the base-case and drawdown scenarios for water temperature, total dissolved solids, dissolved oxygen, total nitrogen, dissolved organic carbon, inorganic suspended sediment, total phosphorus, orthophosphate, nitrate, and ammonia (fig. 6). Chlorophyll $a$ and particulate organic carbon, however, showed notable differences between the base-case and the drawdown scenarios in mid-summer and early autumn. For those two constituents, the lower water-surface elevation produced higher concentrations at Keno Dam, compared to the base case at that time of year. In the model, the particulate organic carbon is composed of both dead algal material and matter that entered the reach from the upstream inflow or tributaries. The difference likely is partly attributable to the decreased time available for particulate material to settle under the drawdown scenarios - a factor that was examined in more detail in an analysis of model differences throughout the Link-Keno reach.

\section{Link-Keno Reach}

\section{Algae and Settled Organic Matter}

Elevated chlorophyll $a$ concentration in the Link-Keno reach in summer and early autumn largely was due to algae flowing into Link and Klamath Rivers from Upper Klamath Lake, which has large blooms of the cyanobacterium Aphanizomenon flos-aquae at that time of year. During much of the summer, that species of algae did not thrive in the Link-Keno reach, so an important process was its settling, death, and decomposition. Thus, the highest algae and chlorophyll $a$ concentrations occurred in the upstream end of the reach, near the mouth of Link River (base case, fig. 7A). Photosynthesis and oxygen production by algae still occurred, but at times could be overwhelmed by decomposition processes leading to anoxia or hypoxic conditions at certain locations and periods of time. With a 4-ft water-surface elevation drawdown, the model showed higher concentrations of algae and chlorophyll $a$ moving farther downstream towards Keno Dam before settling from the water column (fig 7B), owing to the higher water velocities in that scenario than in the base-case scenario. The differences in the modeled chlorophyll $a$ concentrations are shown in figure $8 A$, and an increase in the peak chlorophyll $a$ concentration was discernable at the Miller Island monitoring site (model segment 38 , fig. $8 B$ ). 

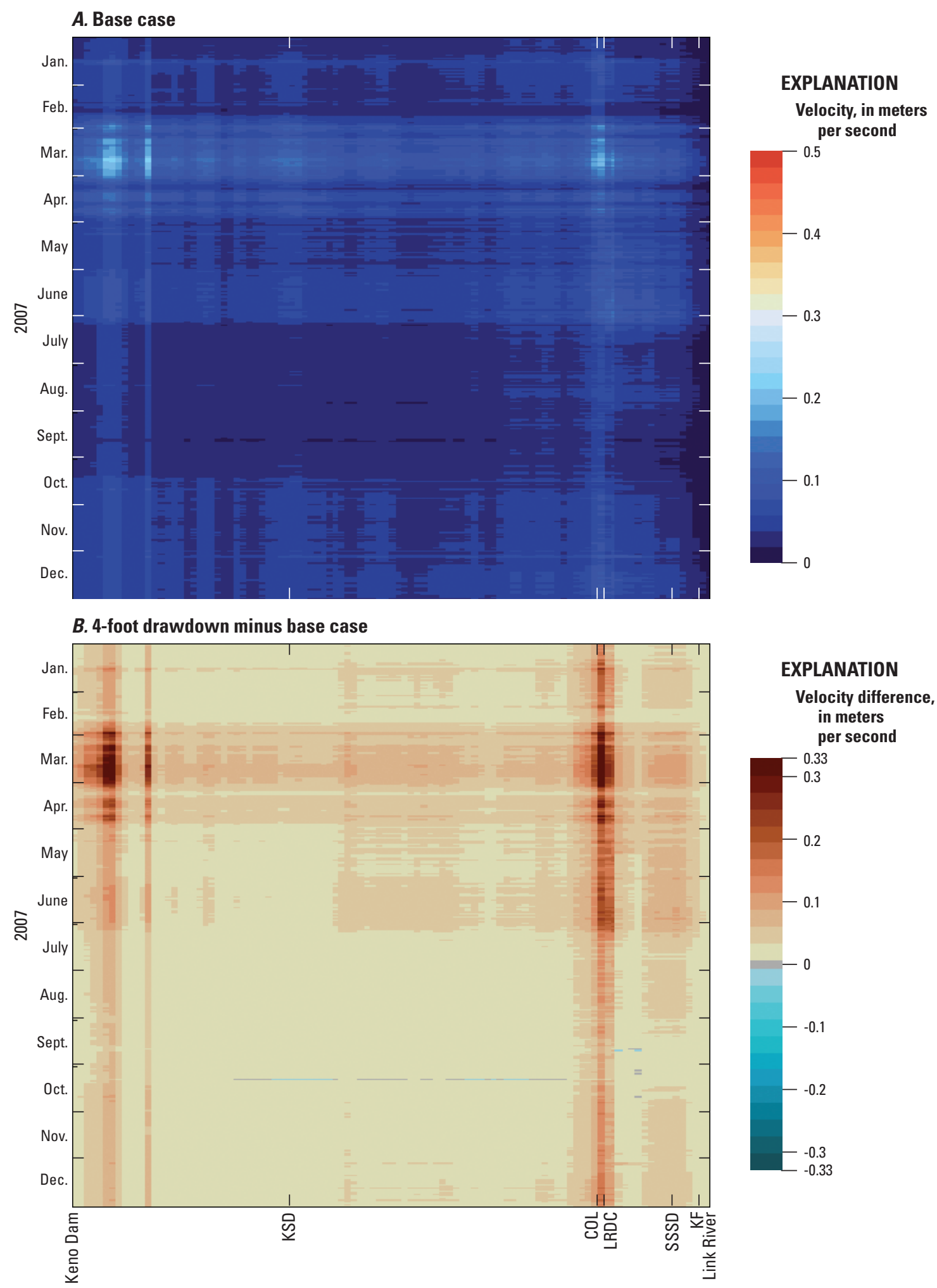

Figure 4. Modeled water velocity in the year 2007 base case $(A)$, and modeled velocity difference between the 4-foot drawdown scenario and the base-case model $(B)$, in the Link River to Keno Dam reach of the Klamath River, south-central Oregon. Colors correspond to model-segment averages across the modeled reach and for the whole year. X-axis represents the Klamath River reach from Link River mouth (right) to Keno Dam (left). X-axis labels are the locations of inflows and point sources: KF, Klamath Falls wastewater treatment plant (WWTP); SSSD, South Suburban WWTP; LRDC, Lost River Diversion Channel; COL, Columbia Forest Products; KSD, Klamath Straits Drain. Positive velocity differences in $(B)$ indicate that the 4-foot drawdown scenario had higher velocities than the base case. 

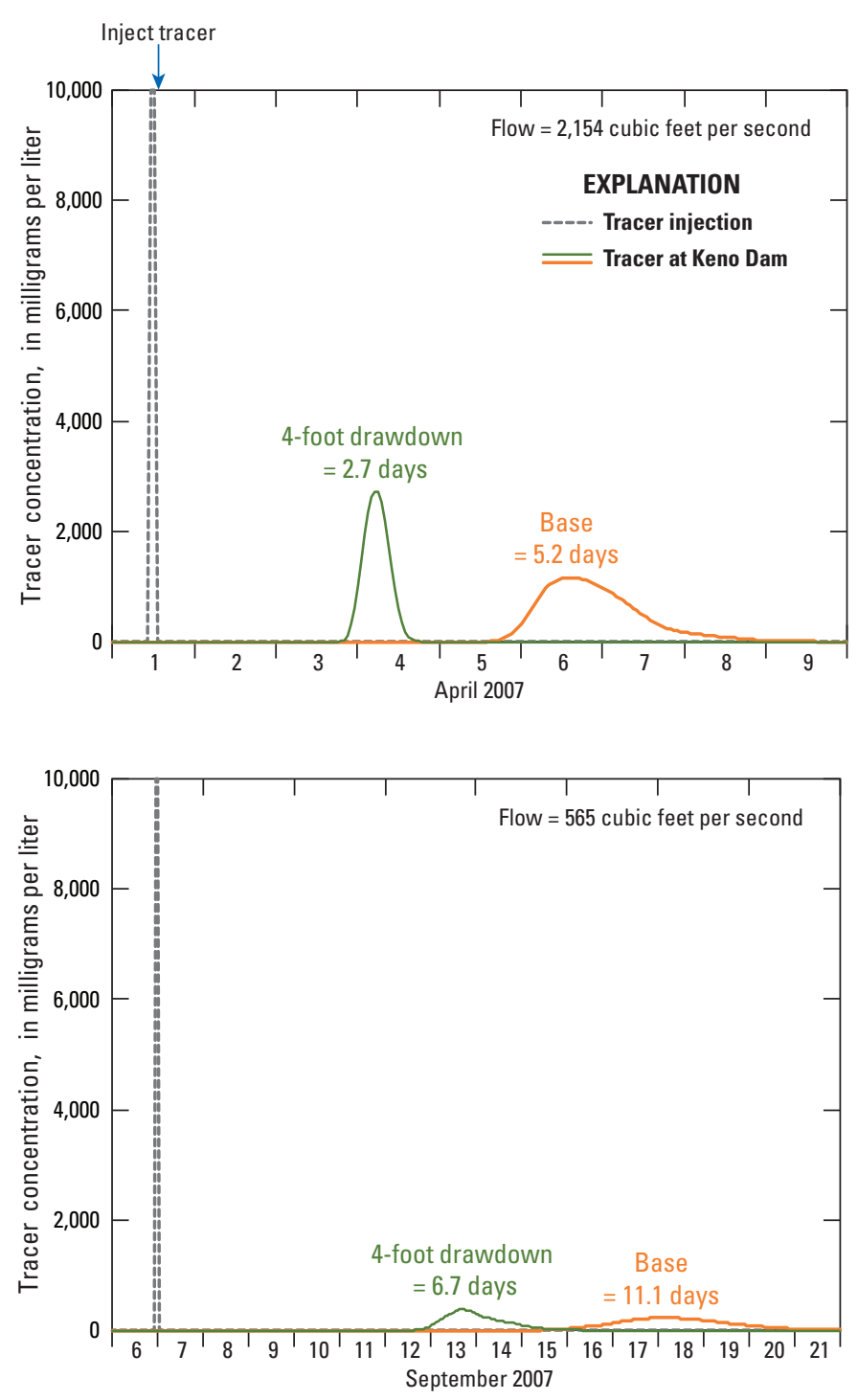

Figure 5. Model tracer results from addition of a hypothetical tracer at the mouth of Link River (black peak, dashed lines) and downstream tracer concentrations at the Keno Dam outflow indicating the time required for the tracer peak to reach Keno Dam (solid-line peaks), south-central Oregon, during 2007. Model tracer runs were started on April 1, 2007, with flow at 2,154 cubic feet per second ( $\mathrm{ft} 3 / \mathrm{s})$ (61 cubic meters per second $\left.\left[\mathrm{m}^{3} / \mathrm{s}\right]\right)$ (top graph), and September 7, 2007, with flow at $565 \mathrm{ft} 3 / \mathrm{s}\left(16.0 \mathrm{~m}^{3} / \mathrm{s}\right)$ (bottom graph).

If the decreased travel time under a drawdown scenario affected the mass flux and deposition location of settling particulate material, then that hypothesis can be tested by examining the model first-order sediment compartment (fig. 9). Decomposition of organic material is another process that controls how much material is in the model first-order sediment compartment. In the CE-QUAL-W2 model, the first-order sediment compartment tracks the mass of settled algae and organic matter that settles to the river bottom and the oxygen demand from their decay. The dissolved oxygen status of the overlying water matters, such that decomposition does not occur when oxygen concentrations are less than a threshold of $0.1 \mathrm{mg} / \mathrm{L}$. In the base-case model, the distribution of first-order sediment (fig. $9 \mathrm{~A}$ ) showed that a large quantity of organic matter, much of it derived from algae, settled in the upper part of the Link-Keno. With a 4-ft drawdown, the model showed relatively less accumulation of settled organic matter in those upper reaches (fig. 9B). Instead, the algae and particulate organic matter had a higher chance of being swept farther downstream by the higher velocities, which resulted in relatively more settling in downstream reaches and higher concentrations in the Keno Dam outflow in summer and autumn when the blooms occurred (fig. 6).

\section{Dissolved Oxygen}

The CE-QUAL-W2 model considers various sinks and sources of dissolved oxygen, including inflow concentrations, atmospheric exchange across the river surface, algal photosynthesis and respiration, ammonia and nitrate oxidation, and organic matter decay in the water column and sediments. Although modeled dissolved oxygen concentrations in the Keno Dam outflow indicated that overall changes were minor in the drawdown scenarios (fig. 6), some spatial variability in dissolved oxygen results in the Link-Keno reach (fig. 10) merited a more-detailed examination because oxygen levels influence many processes in the model and are important to aquatic life.

The segment-average, daily-average results showed that simulated dissolved oxygen concentrations changed by as much as $2.0 \mathrm{mg} / \mathrm{L}$ in the $4-\mathrm{ft}$ drawdown scenario (fig. 10). Concentrations increased and decreased in that scenario, depending on day and location. An examination of results over the depth of the water column at two locations indicated that areas of hypoxia and anoxia $(<0.1 \mathrm{mg} / \mathrm{L})$ in spring through autumn were more limited in the drawdown scenario (fig. 11). Where anoxic water is in contact with the sediment, aerobic decomposition of organic matter in the surficial, first-order sediments would not occur. The increase in dissolved oxygen at Keno (segment 95) in late June in the $4 \mathrm{ft}$ drawdown scenario likely was due to the increased quantity of photosynthesizing algae at that downstream location compared to the base case.

\section{Water Temperature}

Water temperature in the Keno Dam outflow was similar in the base case and drawdown scenarios (fig. 6), but some important spatial differences in water temperature occurred within the Link-Keno reach, with differences as large as 2.0 ${ }^{\circ} \mathrm{C}$ on a segment-average, daily average basis (fig. 12). The shallower water depths of the 4-ft drawdown scenario might not allow for some of the vertical stratification that occurred in the deeper water of the base-case scenario, particularly in springtime when the flows were higher. The 4-ft drawdown scenario showed slightly smaller temperature differences with depth throughout the water column compared to the base case at Miller Island, a site in the middle of the Link-Keno reach (fig. 13). The strong seasonal pattern in water temperature was 

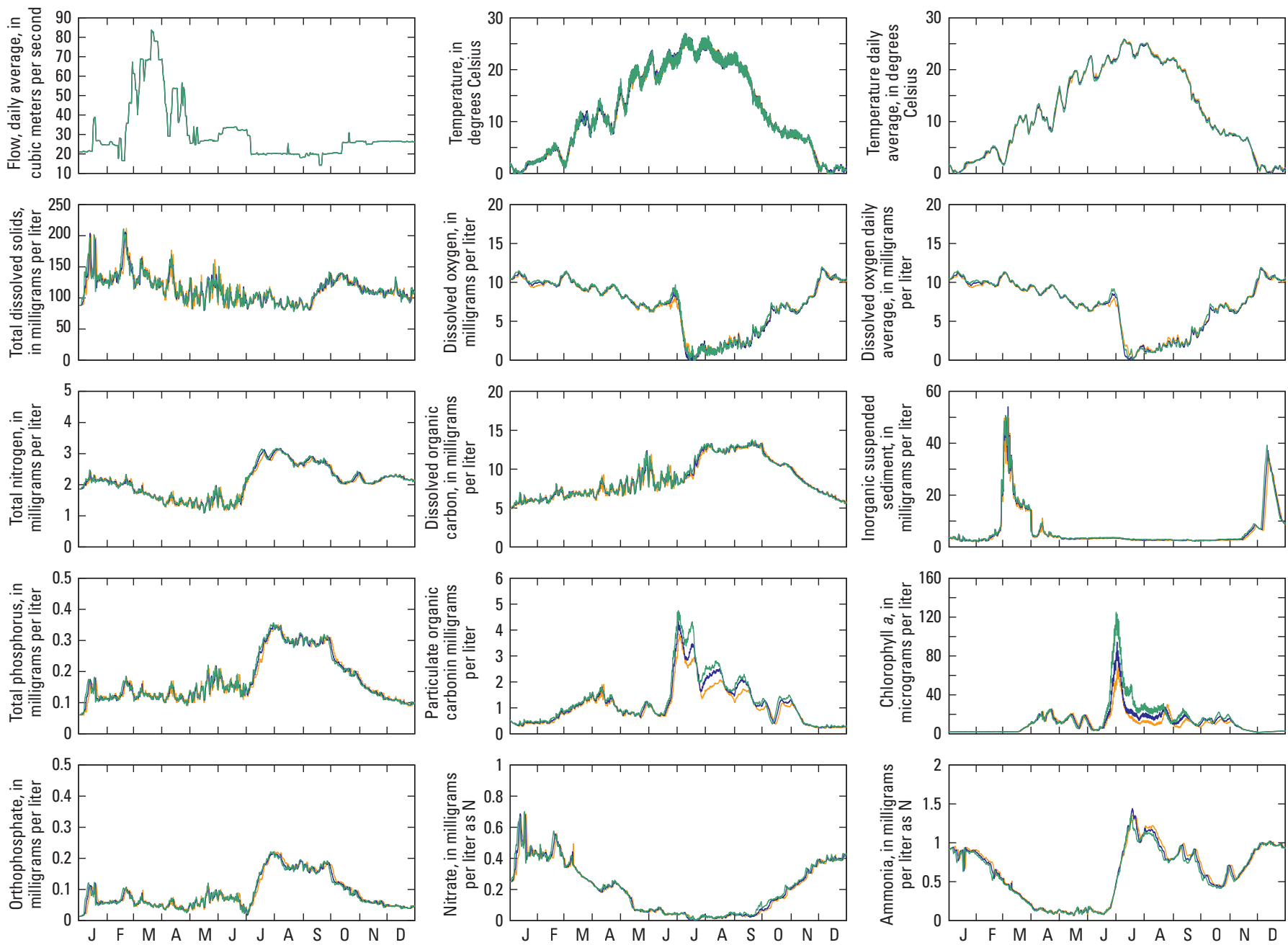

EXPLANATION

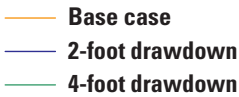

Figure 6. Modeled flow, temperature, and water-quality constituents in the outflow of Keno Dam for the base case, and the 2- and 4-foot drawdown scenarios, in the Link River to Keno Dam reach of the Klamath River, south-central Oregon, during 2007. Macrophyte effects are not included in these runs.

relatively unaltered, with slightly different levels of thermal stratification due to shallower depths constituting most of the differences.

\section{Model Scenarios With Macrophytes}

Several species of aquatic plants (macrophytes) were present in field surveys from 2011, and those field data were used to calibrate the model rates and parameters for macrophytes in the Link-Keno model (Sullivan, Rounds, and others, 2013), but extrapolating model predictions of macrophyte growth to the lower water-surface elevations in these scenarios involves greater uncertainty. The algorithms used by the CE-QUAL-W2 model to simulate macrophyte growth depend on water depth, cross-sectional shape, initial conditions, and light extinction rates, among other factors. A lower water level possibly could influence the colonization of channel margins or parts of the Link-Keno reach by the same or different species of macrophytes in ways that do not mirror the conditions measured in 2011. To the extent that macrophytes in a drawdown scenario might colonize and grow in areas that were similar to the base case, simulating the presence of macrophytes was determined to be useful at least as a sensitivity test, and as a means of gaining insight into the potential importance of the influence of macrophytes on water quality in a drawdown scenario. 

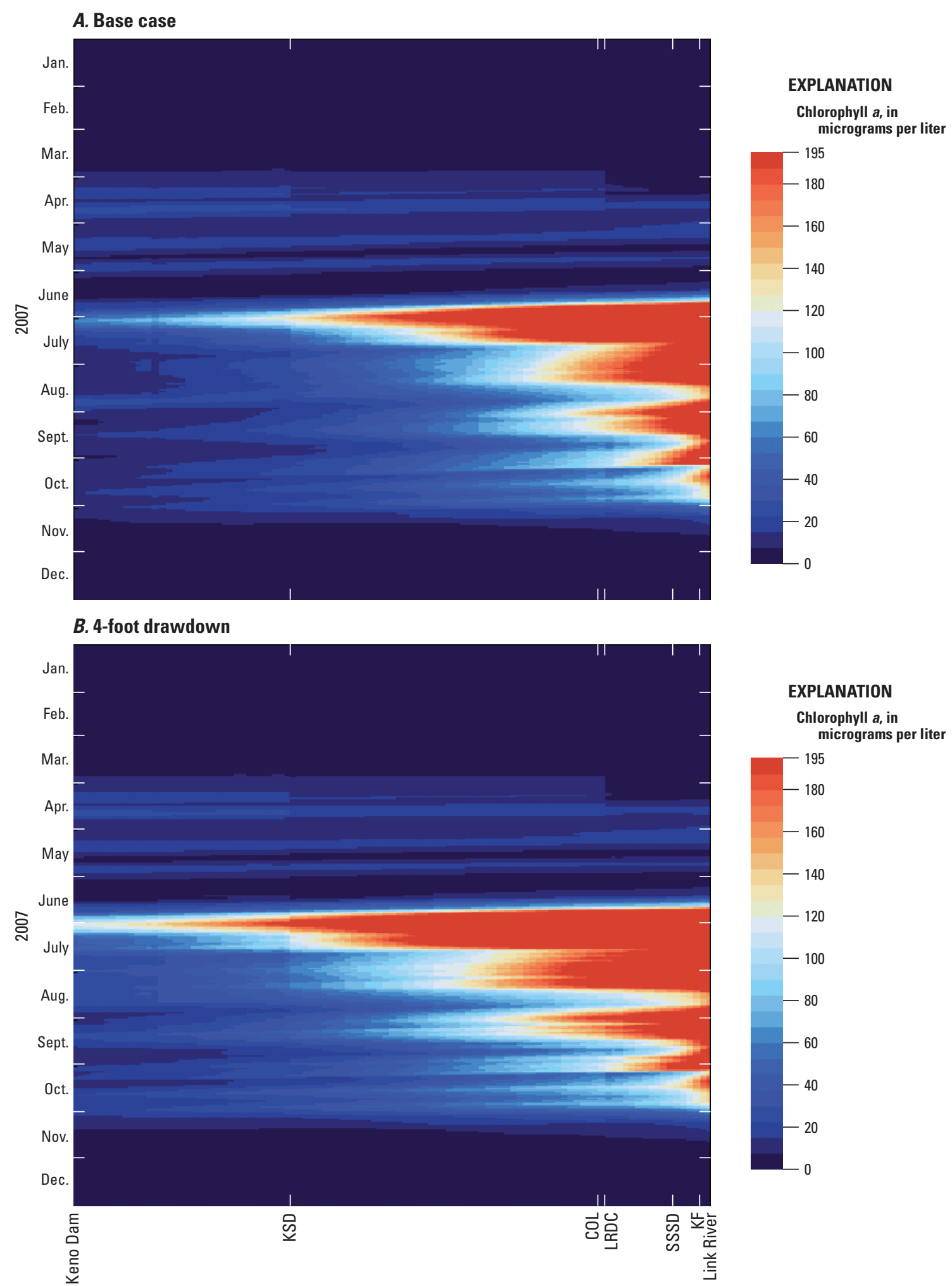

Figure 7. Modeled chlorophyll a concentration for the year 2007 base case $(A)$, and the 4 -foot drawdown scenario $(B)$, in the Link River to Keno Dam reach of the Klamath River, south-central Oregon. Colors correspond to model-segment averages across the modeled reach and for the whole year. X-axis represents the Klamath River reach from Link River mouth (right) to Keno Dam (left). X-axis labels are the locations of inflows and point sources: KF, Klamath Falls wastewater treatment plant (WWTP); SSSD, South Suburban WWTP; LRDC, Lost River Diversion Channel; COL, Columbia Forest Products; KSD, Klamath Straits Drain. Note: To emphasize the spatial pattern, values are capped in these two plots. Values greater than 195 micrograms per liter ( $\mu \mathrm{g} / \mathrm{L})$ are plotted as $195 \mu \mathrm{g} / \mathrm{L}$. Actual modeled chlorophyll a concentrations could be as much as $600 \mu \mathrm{g} / \mathrm{L}$ or more. 


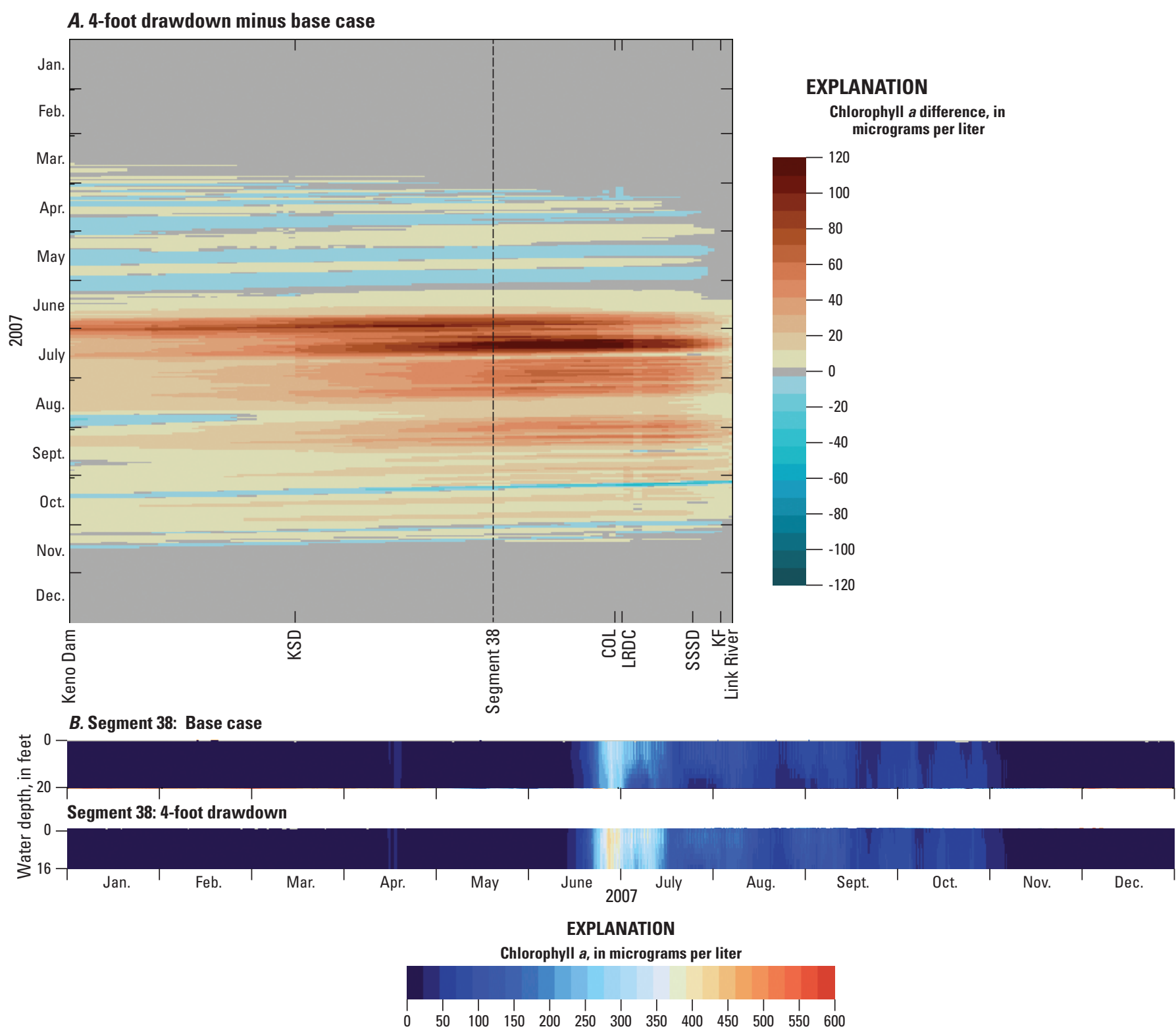

Figure 8. Modeled difference in segment-averaged chlorophyll a concentration between the 4-foot drawdown and the base-case scenarios $(A)$, and depth profiles showing chlorophyll $a$ at model segment 38 near Miller Island for the base case (top) and 4-foot drawdown scenario (bottom) (B), in the Link River to Keno Dam reach of the Klamath River, south-central Oregon, during 2007. X-axis labels are the locations of inflows and point sources: KF, Klamath Falls wastewater treatment plant (WWTP); SSSD, South Suburban WWTP; LRDC, Lost River Diversion Channel; COL, Columbia Forest Products; KSD, Klamath Straits Drain. Profiles are plotted every 0.2 day, with colors representing chlorophyll a concentrations.

Base-case and 4-ft drawdown scenario results at the Keno Dam outflow location were largely similar after adding macrophytes back into the model (fig. 14), with a few exceptions. Particulate organic carbon and chlorophyll $a$ showed increases in the drawdown scenario in the same manner as results from the without-macrophytes model runs (fig. 6). Similarly, those effects were attributable to the higher velocities and less time for settling. Unlike the without-macrophytes simulations, however, dissolved oxygen showed a notable decrease in the outflow between the base case and a 4-ft drawdown when macrophytes were included in the simulation. The daily fluctuation in dissolved oxygen also was greater with macrophytes enabled, owing to the greater combined primary production and respiration of macrophytes and algae together. Modeled dissolved oxygen fluxes showed decreased oxygen production and respiration in the drawdown scenarios compared to the base case, particularly for the macrophytes (fig. 15A), that led to the lower dissolved oxygen concentrations in the outflow. Whole-reach dissolved oxygen fluxes for algae (fig. 15B) were more similar for the various water-level scenarios. 

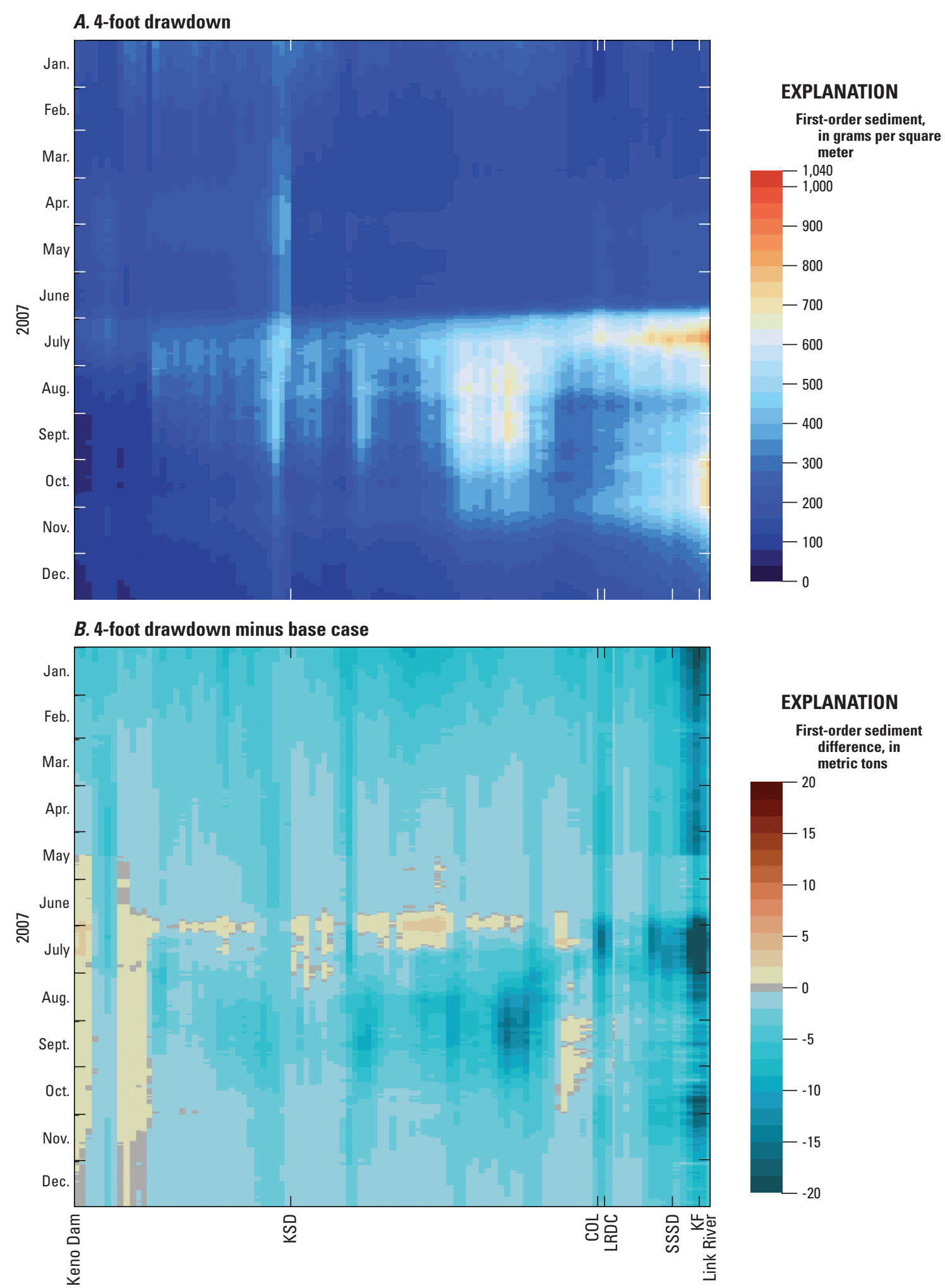

Figure 9. Modeled settled organic matter in the first-order sediment compartment for the year 2007 base case $(A)$, and the difference in modeled settled organic matter mass between the 4-foot drawdown scenario and the base case $(B)$, in the Link River to Keno Dam reach of the Klamath River, south-central Oregon. Macrophyte effects are not included in these model runs. All values are model-segment averages $(A)$, or totals $(B)$ for the whole year. X-axis represents the reach from Link River mouth (right) to Keno Dam (left). X-axis labels are the locations of inflows and point sources: KF, Klamath Falls wastewater treatment plant (WWTP); SSSD, South Suburban WWTP; LRDC, Lost River Diversion Channel; COL, Columbia Forest Products; KSD, Klamath Straits Drain. 


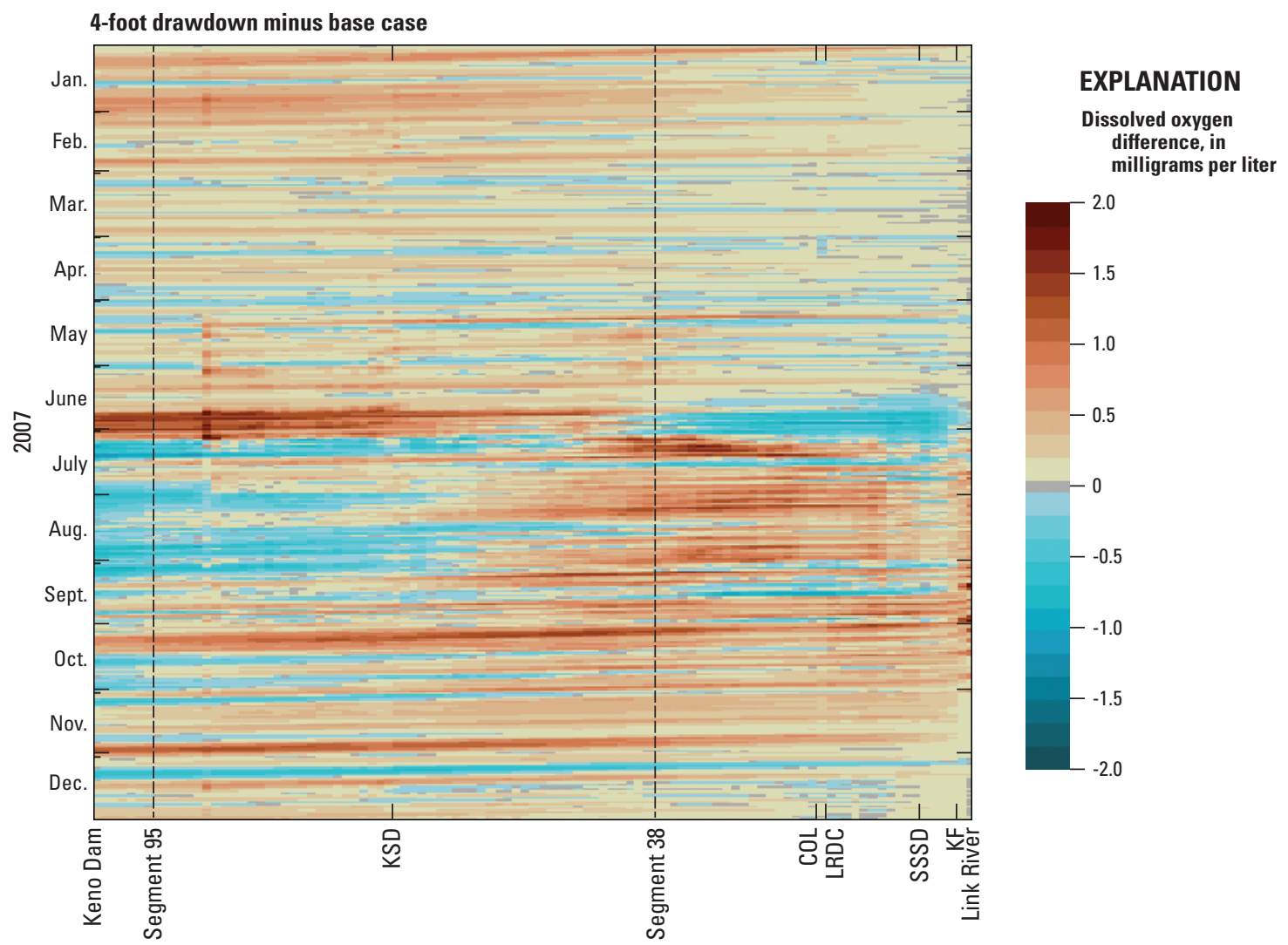

Figure 10. Modeled difference between dissolved oxygen concentration in the 4-foot drawdown scenario and the year 2007 base case, in the Link River to Keno Dam reach of the Klamath River, south-central Oregon. Positive values represent times and locations of dissolved oxygen increases in the drawdown scenario and negative values represent times and locations of dissolved oxygen decreases. Macrophyte effects are not included in these model runs. All values are model-segment averages across the modeled reach and for the whole year. X-axis represents the reach from Link River mouth (right) to Keno Dam (left). X-axis labels are the locations of inflows and point sources: KF, Klamath Falls wastewater treatment plant (WWTP); SSSD, South Suburban WWTP; LRDC, Lost River Diversion Channel; COL, Columbia Forest Products; KSD, Klamath Straits Drain.

Several possible reasons might explain the decreased oxygen production from macrophytes in the drawdown scenario. In the 2011 Link-Keno macrophyte survey, macrophytes were limited to shallow areas throughout the reach, including shallow waters along the edges of the Klamath River. Macrophytes were not found in deep water because the relatively high light extinction from dissolved organic matter restricted the available light needed by those plants in deep-water habitats. The bathymetry for the model grid, based on a field survey, resulted in slightly shallower slopes near the river edges in the base case, as compared to the slopes occurring at the river edges in the drawdown scenarios. As a result, macrophytes in the drawdown scenario had a smaller area of nearshore habitat with ideal light conditions compared to the base case.

Vertical profiles of dissolved oxygen at two locations from model runs with macrophytes enabled (fig. 16) showed patterns that were similar to those run without macrophytes (fig. 11). The 4-ft drawdown scenario had less frequent anoxia at the river bottom, but the overall patterns were similar, with large oxygen demands co-occurring with the presence of large algal abundances moving through the river in July and August. The deposited organic matter from that algae continued to exert an oxygen demand at upstream locations through September.

The model results with macrophytes enabled should be treated with higher uncertainty for multiple reasons. First, a lower water level possibly could lead to different macrophyte species colonizing the reach; this possibility was not captured with the existing model. A water-level drawdown also possibly could alter the nearshore bathymetry over time owing to erosion or deposition, thereby affecting the amount of shallow nearshore habitat for macrophytes. Regardless of this, the model shows that macrophyte dynamics could be a substantial factor affecting dissolved oxygen concentrations and patterns with a drawdown of the Link-Keno reach. 


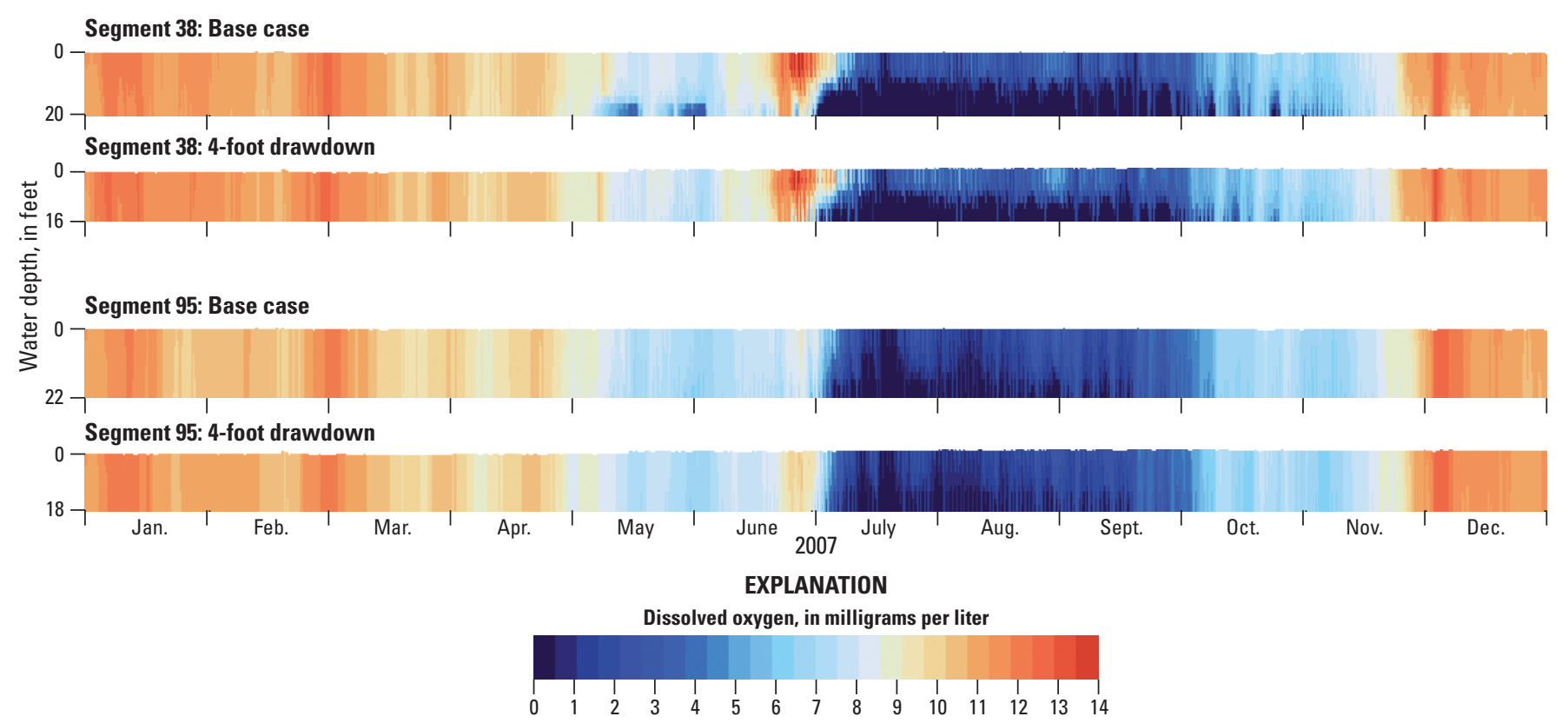

Figure 11. Dissolved-oxygen profiles showing changes in dissolved oxygen concentrations at segments 38 (Miller Island) and 95 (Keno Bridge), with depth, during 2007, in the Link River to Keno Dam reach of the Klamath River, south-central Oregon. Output is every 0.2 day. Macrophyte effects are not included in these model runs. 


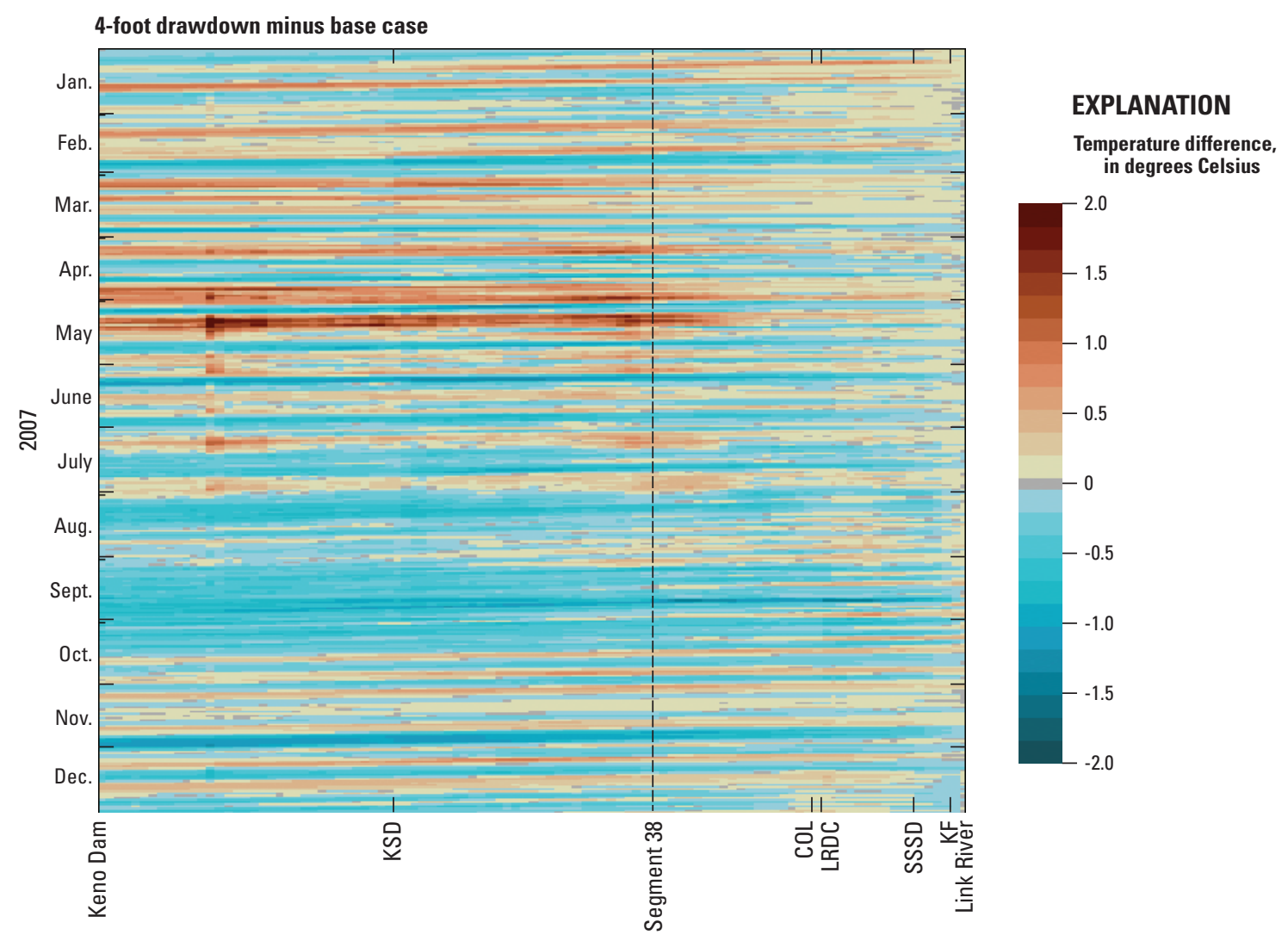

Figure 12. Modeled difference between water temperature in the 4-foot drawdown scenario and the year 2007 base case, in the Link River to Keno Dam reach of the Klamath River, south-central Oregon. Positive values represent times and locations of temperature increase in the drawdown scenario and negative values represent times and locations of temperature decreases. Macrophyte effects are not included in these model runs. Colors correspond to model-segment averages across the modeled reach and for the whole year. X-axis represents the Klamath River reach from Link River mouth (right) to Keno Dam (left). X-axis labels are the locations of inflows and point sources: KF, Klamath Falls wastewater treatment plant (WWTP); SSSD, South Suburban WWTP; LRDC, Lost River Diversion Channel; COL, Columbia Forest Products; KSD, Klamath Straits Drain. Segment 38 is the location of the Miller Island sampling location.

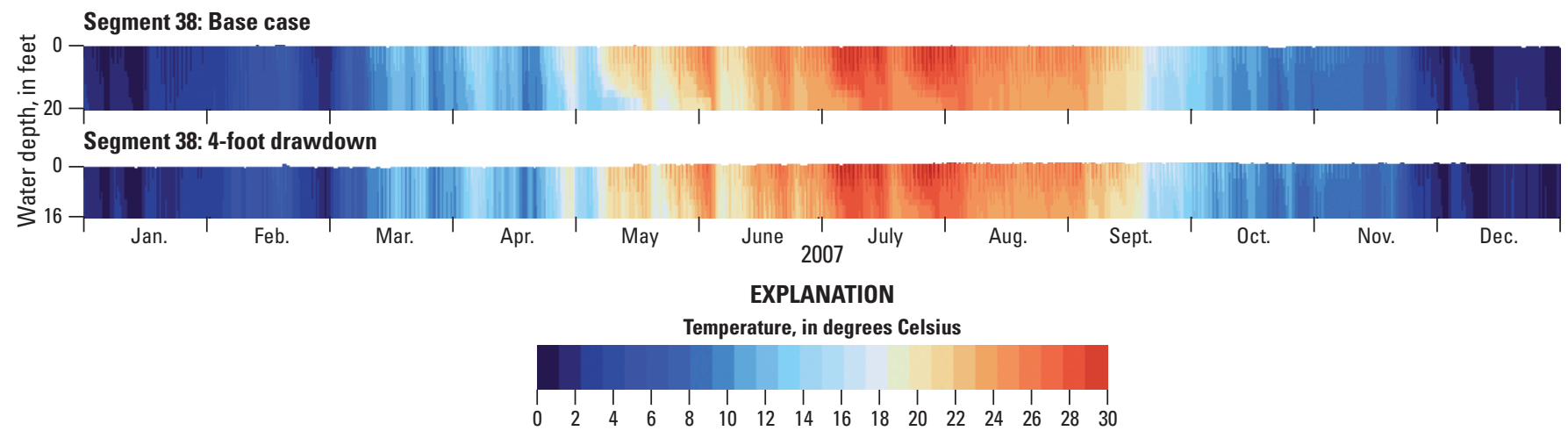

Figure 13. Water-temperature profiles showing changes in water temperature at segment 38 (Miller Island), with depth, during 2007, in the Link River to Keno Dam reach of the Klamath River, south-central Oregon. Output is every 0.2 day. Macrophyte effects are not included in these model runs. 

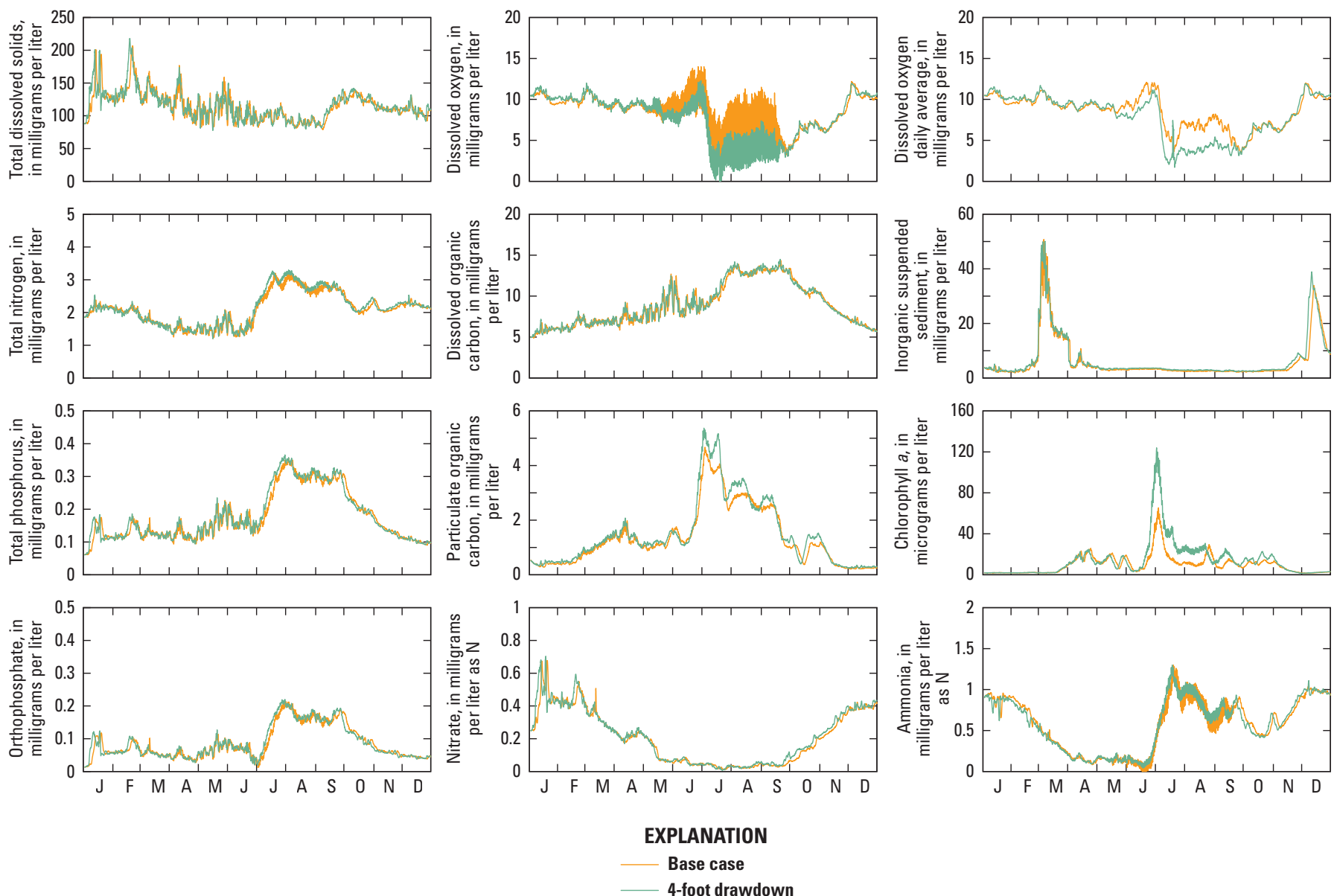

Figure 14. Modeled flow, temperature, and water-quality constituents in the outflow of Keno Dam for the base case and 4-foot drawdown scenarios, Klamath River, south-central Oregon. Macrophyte effects are included in these runs. 

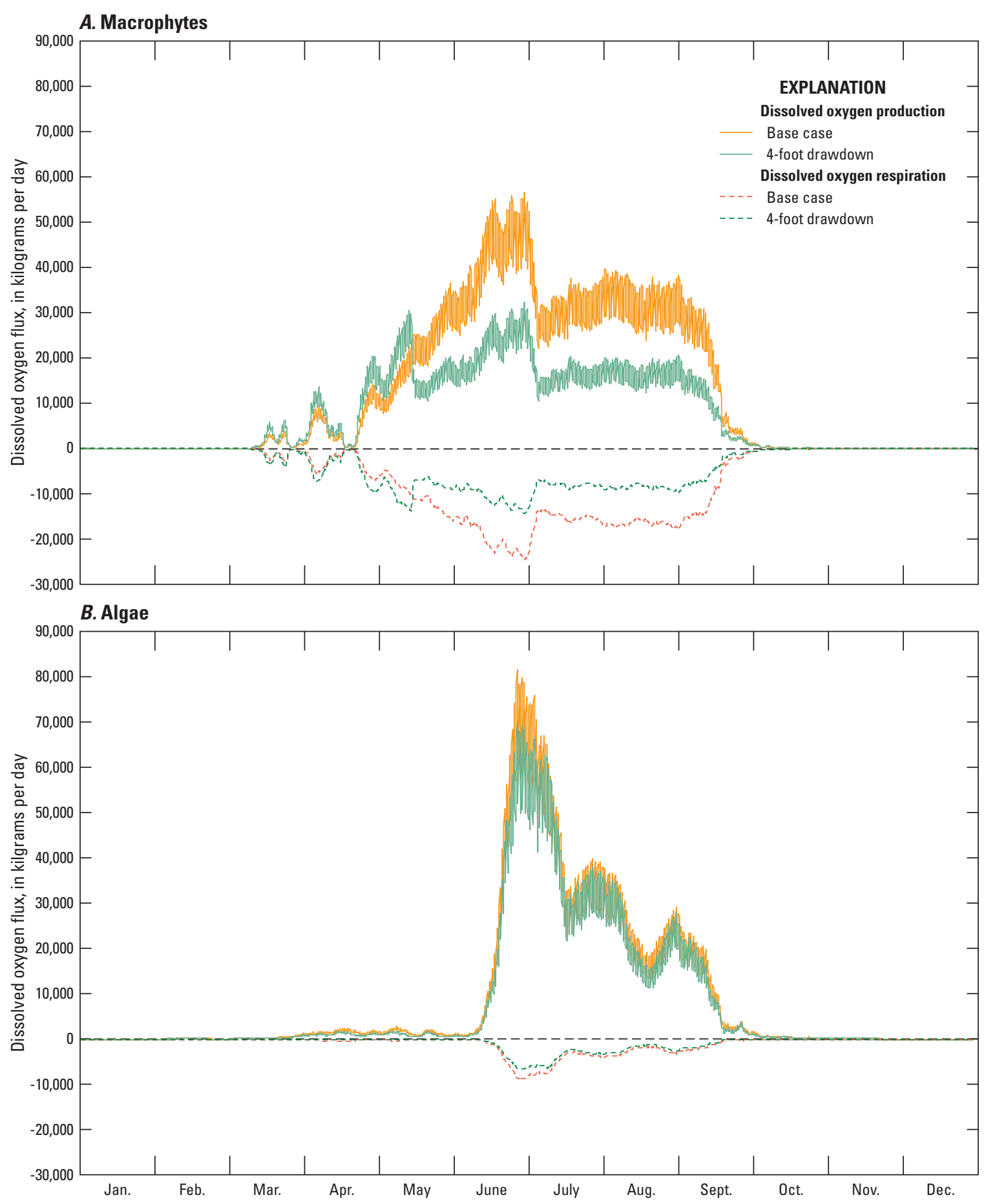

Figure 15. Dissolved-oxygen production and respiration fluxes, as modeled with the presence of macrophytes, for macrophytes $(A)$, and algae $(B)$ for the entire Link-Keno reach, Klamath River, south-central Oregon. 


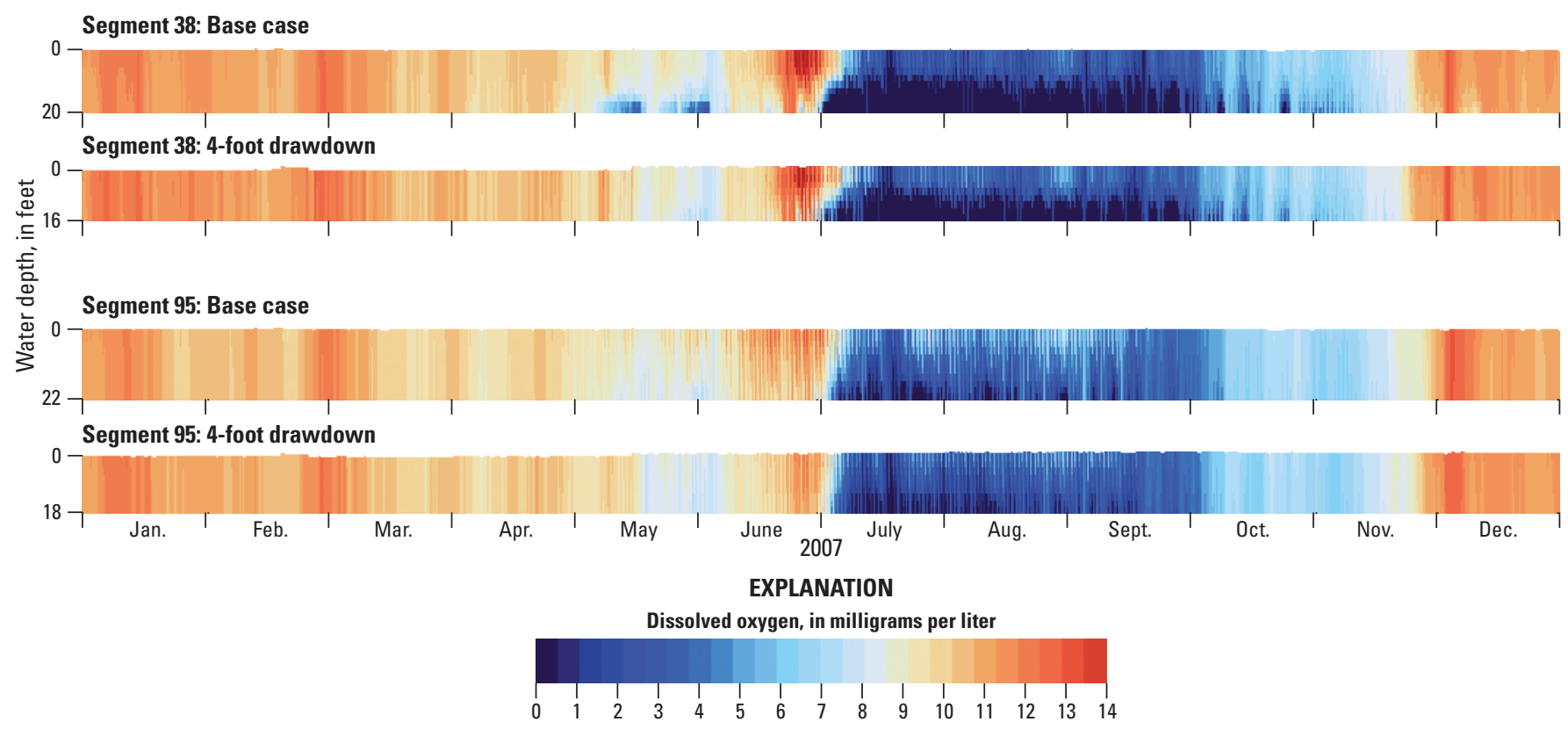

Figure 16. Dissolved oxygen profiles showing changes in dissolved oxygen concentrations at segments 38 (Miller Island) and 95 (Keno Bridge), with depth, during 2007. Output is every 0.2 day. Macrophyte effects are included in these model runs.

\section{Acknowledgments}

The authors gratefully acknowledge Rick Carlson (Bureau of Reclamation), Mike Deas (Watercourse Engineering), and Brian Cluer and Shari Whitmore (National Oceanic and Atmospheric Administration) for providing insights and helpful discussions during this study. Comments from two peer reviewers also improved this report.

\section{References Cited}

Cole, T.M., and Wells, S.A., 2008, CE-QUALW2-A twodimensional, laterally averaged, hydrodynamic and waterquality model, version 3.6: U.S. Army Corps of Engineers, Instruction Report EL-08-1 [variously paged].

Dicken, S.N., and Dicken, E.F., 1985, The legacy of ancient Lake Modoc-A historical geography of the Klamath Lakes Basin: Distributed by University of Oregon Bookstore, Eugene, Oregon [variously paged].

Hoyt, J.C., McGlashan, H.D., and Dean, H.J., 1913, Water Resources of California, Part III, Stream measurements in the Great Basin and Pacific Coast river basins: U.S. Geological Survey Water-Supply Paper 300, 956 p., https://doi.org/10.3133/wsp300.
Oregon Department of Environmental Quality, 2018, Upper Klamath and Lost River subbasins TMDL and water quality management plan: Oregon Department of Environmental Quality TMDL Program, accessed July 12, 2019, at https://www.oregon.gov/deq/FilterDocs/ klamathlostTMDL2018.pdf.

Sullivan, A.B., Rounds, S.A., Asbill-Case, J.R., and Deas, M.L., 2013, Macrophyte and $\mathrm{pH}$ buffering updates to the Klamath River water-quality model upstream of Keno Dam, Oregon: U.S. Geological Survey Scientific Investigations Report 2013-5016, 52 p., https://doi.org/10.3133/ sir20135016.

Sullivan, A.B., Rounds, S.A., Deas, M.L., Asbill, J.R., Wellman, R.E., Stewart, M.A., Johnston, M.W., and Sogutlugil, I.E., 2011, Modeling hydrodynamics, water temperature, and water quality in the Klamath River upstream of Keno Dam, Oregon, 2006-09: U.S. Geological Survey Scientific Investigations Report 2011-5105, 70 p., https://pubs.usgs.gov/sir/2011/5105/.

Sullivan, A.B., Sogutlugil, I.E., Deas, M.L., and Rounds, S.A., 2014, Water-quality modeling of Klamath Straits Drain recirculation, a Klamath River wetland, and 2011 conditions for the Link River to Keno Dam reach of the Klamath River, Oregon: U.S. Geological Survey Open-File Report 2014-1185, 75 p., https://doi.org/10.3133/ofr20141185.

Sullivan, A.B., Sogutlugil, I.E., Rounds, S.A., and Deas, M.L., 2013, Modeling the water-quality effects of changes to the Klamath River upstream of Keno Dam, Oregon: U.S. Geological Survey Scientific Investigations Report 2013-5135, 60 p., https://doi.org/10.3133/sir20135135. 
Publishing support provided by the U.S. Geological Survey Science Publishing Network, Tacoma Publishing Service Center

For more information concerning the research in this report, contact the Director, Oregon Water Science Center

U.S. Geological Survey

2130 SW 5th Avenue

Portland, Oregon 97201

https://www.usgs.gov/centers/or-water 
